\title{
Effect of Fruiting Habit Traits on Fruit Yield and Its Contributing Traits in Chilli (Capsicum annuum L.)
}

\author{
C. Anilkumar*, A. Mohan Rao ${ }^{1}$, B. Bhavani ${ }^{1}$ and S. Ramesh ${ }^{1}$ \\ Department of Genetics and Plant Breeding \\ University of Agricultural Sciences \\ Bengaluru, India
}

\begin{abstract}
Chilli (Capsicum annuum L.) produces fruits with varying orientation and number at each node. They are considered as fruiting habit traits in chilli. Farmer, producer and consumer preference for fruiting habit traits varies from region to region. For increased acceptability by farmers and consumers, high yielding cultivars should be bred with preferred fruiting habit traits. An investigation was carried out to study the influence of fruiting habit traits on fruit yield and its components in chilli at Bengaluru, India. The F2 individuals derived from crosses involving parents differing for single or both fruiting habit traits were grouped into fruiting habit classes. The means of fruiting habit classes in F2 populations were compared and statistically tested. The non-significant mean differences of fruiting habit classes for fruit yield and its components indicated lack of influence of fruiting habit traits on fruit yield and its components.
\end{abstract}

Keywords: Fruiting habit traits, fruits per node, orientation, yield per plant

\section{INTRODUCTION}

Chilli (Capsicum annuum L.) is one of the most important commercial and spice crops of India. Chilli produces fruits with varying orientation and number referred to as fruiting habit. Fruit orientation is either pendant or erect (Lee et al., 2008) and number of fruits at a node is either one (solitary) or more than one (clustered). The fruit orientation is inherited by a recessive gene in chilli (Lee, 1994). Farmer/producer and consumer preferences for fruiting habit varies from region to region in India. Hence, fruit yield, the edible/economic product need to be maximized under preferred fruit habit background. We hypothesize that fruit yield in chilli is not affected by fruit habit. Thus, it should be possible to develop high fruit yielding cultivars with preferred combination of fruit habit. Therefore, the present study was carried out to test the hypothesis.

\section{METHODOLOGY}

\section{Evaluation of experimental material}

Six genotypes (Utkal Awa (UA), CMS 6B, CMS 10B, Phule Jyothi (PJ), Pusa Sadabahar (PS) and Japani Long (JL)) showing four distinct fruiting habit traits, solitary erect (SE), solitary

\footnotetext{
1 Department of Genetics and Plant Breeding, University of Agricultural Sciences, Bengaluru, India

* Corresponding author: anilcgpb@gmail.com
} 
pendant (SP), clustered erect (CE) and clustered pendant (CP) (Table 1) were chosen for the study.

\section{Experimental material}

Six genotypes were used to generate four types of crosses $(\mathrm{CE} \times \mathrm{SE}, \mathrm{CP} \times \mathrm{SP}, \mathrm{SE} \times \mathrm{CP}$ and $\mathrm{CE} \times \mathrm{SP}$ ) (Table 2) in a polyhouse during 2015 growing season. The plants of four types of crosses were grown and selfed to develop $F_{2}$ populations during 2016 summer at the experimental plots of the Department of Genetics and Plant Breeding (GPB), University of Agricultural Sciences (UAS), Bengaluru, India. The $F_{2}$ population derived from four types of crosses involving six parental genotypes were the experimental material.

Table 1. Fruiting habit traits of the genotypes used in the study

\begin{tabular}{lcc}
\hline Genotype & Source & Fruiting habit \\
\hline Utkal Awa & OUAT, Bhubaneshvar, India & Solitary and erect fruits \\
CMS 6B & AVRDC, Taiwan & Solitary and pendant fruits \\
CMS 10B & AVRDC, Taiwan & Solitary and pendant fruits \\
Phule Jyothi & MPKV, Rahuri, India & Clustered and pendant fruits \\
Pusa Sadabahar & Pusa, New Delhi, India & Clustered and erect fruits \\
Japani long & Pusa, New Delhi, India & Clustered and erect fruits \\
\hline
\end{tabular}

\section{Evaluation of experimental material}

Forty day old seedlings of $F_{2}$ generations were planted during the growing season in 2016 and 2017 by maintaining a spacing of $0.75 \mathrm{~m}$ between rows and $0.45 \mathrm{~m}$ between plants within a row at the experimental plots of the Department of GPB, UAS, Bengaluru, India. Upon fruiting, the plants in each $\mathrm{F}_{2}$ population were grouped into different fruiting habit classes i.e. SE, SP, CE and CP based on visual assessment. Data were recorded on all individual plants in each fruiting habit class in $\mathrm{F}_{2}$ generations for fruit length, average fruit weight, fruits per plant and green fruit yield. The two crosses $(\mathrm{JL} \times \mathrm{UA}$ and $\mathrm{PJ} \times \mathrm{CMS} 10 \mathrm{~B})$ which differed for single fruiting habit trait (fruits per node) segregated into two fruiting habit classes (3SE and 1CE, and $3 \mathrm{SP}$ and $1 \mathrm{CP}$, respectively) in $\mathrm{F}_{2}$ generation. On the other hand, other two crosses (UA $\times$ $\mathrm{PJ}$ and PS $\times$ CMS $6 \mathrm{~B}$ ) which differed for two fruiting habit traits (fruits per node and fruit orientation) segregated into four fruiting habit classes (9SP, 3CP, 3SE and 1CE).

Table 2. Types of crosses generated in the experiment

\begin{tabular}{ll}
\hline Crosses & \multicolumn{1}{c}{ Type of cross } \\
\hline Japani Long $(\mathrm{JL}) \times$ Utkal Awa (UA) & Clustered Erect $(\mathrm{CE}) \times$ Solitary Erect $(\mathrm{SE})$ \\
Phule Jyothi $(\mathrm{PJ}) \times$ CMS 10B & Clustered Pendant $(\mathrm{CP}) \times$ Solitary Pendant $(\mathrm{SP})$ \\
Utkal Awa $(\mathrm{UA}) \times$ Phule Jyothi $(\mathrm{PJ})$ & Solitary Erect $(\mathrm{SE}) \times$ Clustered Pendant $(\mathrm{CP})$ \\
Pusa sadabahar $(\mathrm{PS}) \times$ CMS 6B & Clustered Erect $(\mathrm{CE}) \times$ Solitary Pendant $(\mathrm{SP})$ \\
\hline
\end{tabular}




\section{Statistical analysis}

The average fruit yield and its component traits of the $\mathrm{F}_{2}$ individuals classified under two fruiting habit classes and four fruiting habit classes were computed. The significant differences in average fruit yield and its component traits between two fruiting habit classes namely, (1) cluster and single, and (2) pendent and erect were examined using two sample t-test. Significance of differences in fruit yield and its component traits between four fruiting habit classes namely, (1) clustered-erect, (2) clustered-pendent, (3) single-erect and (4) singlependent was examined using F-test (Fisher, 1950). Non significance and significance of $t$ and $\mathrm{F}$ tests indicate lack of influence and significant influence of fruiting habit traits on fruit yield and its component traits, respectively.

\section{RESULTS AND DISCUSSION}

The average fruit number, average fruit weight, fruit length and green fruit yield per plant in $\mathrm{F}_{2}$ populations varied with the type of cross (parental combinations) and also with the fruit habit class in both seasons (Table 3). The magnitude of average fruit weight, fruit number per plant, fruit length and green fruit yield per plant were higher in $\mathrm{F}_{2}$ generations derived from PJ $\times$ CMS 10B compared to those in the $\mathrm{F}_{2}$ generations derived from three other crosses in both seasons. These results clearly indicated the need for preferential allocation of resources for evaluation of segregating generations derived from $\mathrm{PJ} \times \mathrm{CMS} 10 \mathrm{~B}$ for selection of genotypes with desired combination of fruiting habit traits coupled with higher green fruit yield. In $\mathrm{F}_{2}$ generations derived from JL $\times$ UA and PJ $\times$ CMS 10B crosses, the average fruit length, fruits per plant, average fruit weight and green fruit yield per plant were comparable between CE and SE, and SP and CP fruiting habit classes, respectively as indicated by non-significance of two sample t-test (Table 3, Fig.1).

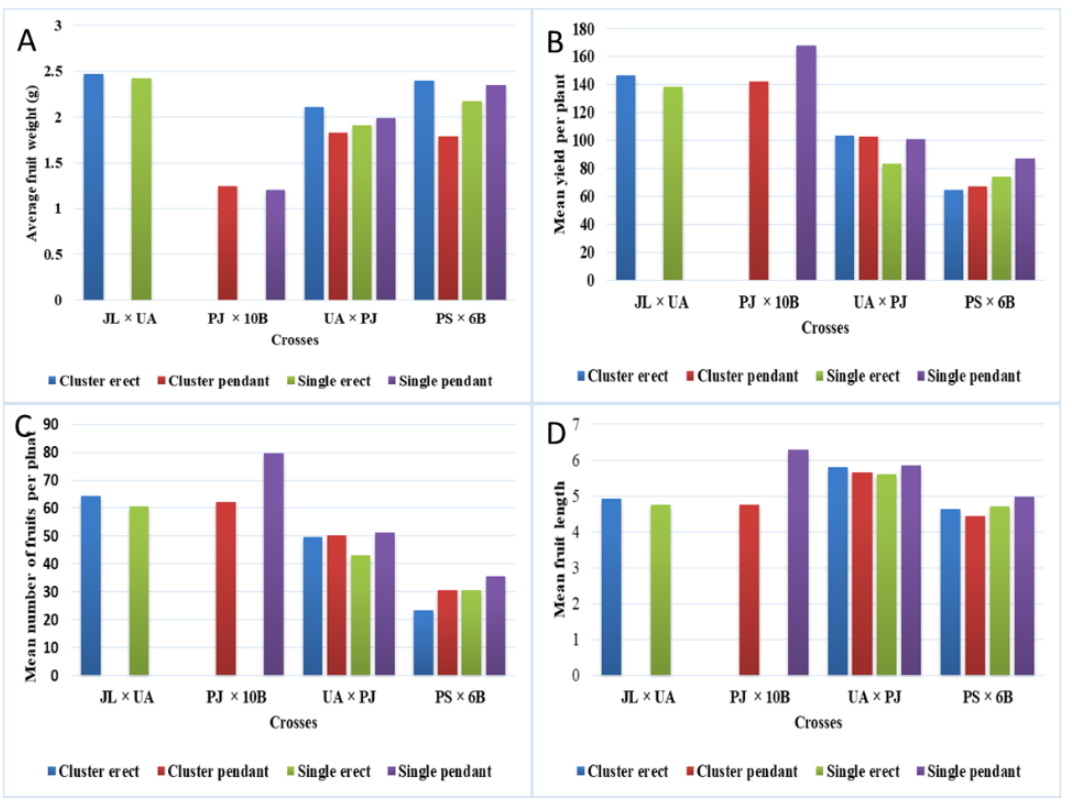

Figure 1. Average (A) fruit weight, (B) fruit yield, (C) number of fruits per plant and (D) fruit length of the $\mathrm{F} 2$ genotypes grouped under different fruiting habit classes 
Table 1. Relationship of fruit habit traits with fruit yield and its component traits of four crosses in chilli over two seasons

\begin{tabular}{|c|c|c|c|c|c|c|c|c|c|c|}
\hline \multirow[t]{2}{*}{ Cross } & \multirow[t]{2}{*}{ Season } & \multirow[t]{2}{*}{ Phenotype Class } & \multicolumn{2}{|c|}{ Fruit length (cm) } & \multicolumn{2}{|c|}{ Fruits per plant } & \multicolumn{2}{|c|}{$\begin{array}{c}\text { Average fruit } \\
\text { weight (g) }\end{array}$} & \multicolumn{2}{|c|}{$\begin{array}{c}\text { Green fruit yield per } \\
\text { plant (g) }\end{array}$} \\
\hline & & & Mean & $\mathbf{P}$ & Mean & $\mathbf{P}$ & Mean & $\mathbf{P}$ & Mean & $\mathbf{P}$ \\
\hline \multirow{2}{*}{ JL } & \multirow{2}{*}{2016} & $\mathrm{CE}$ & 3.80 & \multirow{2}{*}{0.73} & 47.76 & \multirow{2}{*}{0.88} & 3.09 & \multirow{2}{*}{0.78} & 147.96 & \multirow{2}{*}{0.96} \\
\hline & & SE & 3.86 & & 48.57 & & 3.07 & & 148.83 & \\
\hline \multirow{2}{*}{$\begin{array}{l}\times \\
\text { UA }\end{array}$} & \multirow[b]{2}{*}{2017} & $\mathrm{CE}$ & 6.13 & \multirow[b]{2}{*}{0.01} & 80.84 & \multirow[b]{2}{*}{0.28} & 1.90 & \multirow[b]{2}{*}{0.18} & 153.95 & \multirow{2}{*}{0.07} \\
\hline & & $\mathrm{SE}$ & 5.64 & & 72.60 & & 1.79 & & 127.97 & \\
\hline & \multirow{2}{*}{2016} & SP & 8.10 & \multirow{2}{*}{0.14} & 77.94 & \multirow{2}{*}{0.46} & 2.08 & \multirow{2}{*}{0.94} & 166.61 & \multirow{2}{*}{0.60} \\
\hline & & $\mathrm{CP}$ & 7.58 & & 86.35 & & 2.07 & & 182.44 & \\
\hline \multirow{2}{*}{ CMS 10B } & \multirow{2}{*}{2017} & SP & 6.69 & \multirow{2}{*}{0.82} & 102.26 & \multirow{2}{*}{0.40} & 2.12 & \multirow{2}{*}{0.12} & 214.18 & \multirow{2}{*}{0.73} \\
\hline & & $\mathrm{CP}$ & 6.74 & & 93.27 & & 2.28 & & 206.10 & \\
\hline & & SP & 5.84 & & 50.20 & & 2.00 & & 100.38 & \\
\hline & & $\mathrm{SE}$ & 5.72 & & 51.36 & & 1.89 & & 94.60 & \\
\hline & 2016 & $\mathrm{CP}$ & 6.10 & 0.61 & 60.23 & 0.77 & 2.18 & 0.25 & 134.31 & 0.45 \\
\hline & & $\mathrm{CE}$ & 5.73 & & 60.90 & & 1.95 & & 118.75 & \\
\hline $\begin{array}{l}x \\
\text { DI }\end{array}$ & & SP & 5.88 & & 52.23 & & 1.99 & & 101.83 & \\
\hline PJ & & $\mathrm{SE}$ & 6.02 & & 39.62 & & 2.11 & & 80.82 & \\
\hline & 2017 & $\mathrm{CP}$ & 5.70 & 0.57 & 47.96 & 0.39 & 1.75 & 0.11 & 84.36 & 0.52 \\
\hline & & $\mathrm{CE}$ & 5.92 & & 38.61 & & 2.28 & & 84.36 & \\
\hline & & SP & 6.99 & & 31.71 & & 4.62 & & 122.53 & \\
\hline & & $\mathrm{SE}$ & 6.27 & & 39.01 & & 4.10 & & 123.83 & \\
\hline & 2016 & $\mathrm{CP}$ & 7.08 & 0.45 & 28.29 & 0.68 & 4.02 & 0.71 & 109.20 & 0.83 \\
\hline PS & & $\mathrm{CE}$ & 6.70 & & 16.61 & & 5.05 & & 82.00 & \\
\hline & & SP & 7.40 & & 33.90 & & 3.54 & & 113.00 & \\
\hline CMS 6B & & $\mathrm{SE}$ & 7.58 & & 34.01 & & 3.61 & & 114.25 & \\
\hline & 2017 & $\mathrm{CP}$ & 7.32 & 0.94 & 30.10 & 0.92 & 3.64 & 0.92 & 101.17 & 0.86 \\
\hline & & $\mathrm{CE}$ & 7.20 & & 33.80 & & 3.17 & & 97.00 & \\
\hline
\end{tabular}


Similarly, in $\mathrm{F}_{2}$ generations derived from $\mathrm{UA} \times \mathrm{PJ}$ and $\mathrm{PS} \times \mathrm{CMS} 6 \mathrm{~B}$ crosses, the average fruit length, fruits per plant, average fruit weight and green fruit yield per plant were comparable among SP, SE, CP and CE fruiting habit classes as indicated by non-significance of F-tests (Table 3 and Figure.1).

These results have significant bearing on developing high fruit yielding chilli cultivars. It is possible to develop high yielding cultivars with any fruiting habit trait as preferred by different consumer preference segments. Further, as both fruit orientation (Dhamayanthi and Reddy, 2001) and fruits per node (Gopalakrishnan et al., 1989) are monogenically controlled, they could be used as diagnostic descriptors for germplasm characterization and purity assessment, for identifying duplicates in the germplasm, testing true hybridity of crosses and finger printing the varieties for protection of intellectual property associated with their development.

\section{CONCLUSIONS}

Our study suggested lack of effect of fruit habit traits on fruit yield and its component traits.

\section{ACKNOWLEDGEMENT}

Senior author gratefully acknowledges the financial support from university grant commission (UGC), New Delhi, India in the form of National Fellowship for students of other backward classes (NF-OBC) (F./201617/NFO201517OBCKAR47283/ (SAIII/Website) for pursuing Ph.D. Degree at the University of Agricultural Sciences, Bengaluru, India.

\section{REFERENCES}

Fisher, R. A. (1950). Statistical methods for research workers, $11^{\text {th }}$ Edition, Oliver and Boyd, London, UK. p362.

Lee, H, R., Cho, M, C., Kim, H, J., Park, S, W. and Kim, B, D. (2008). Marker development for erect versus pendant oriented fruit in Capsicum annuum L. Mol. Cells, 26, 548-553.

Lee, M. H. (1994). Genetic analysis of determinate plant shape, fruit bearing habit and deciduous character of hot pepper (Capsicum annuum L.). Dissertation, Chungbuk National University, South Korea.

Gopalakrishnan, T. R., Gopalkrishnan, P. K. and Peter, K. V. (1989). Inheritance of clusterness and fruit orientation in chilli (Capsicum annuum L.). Indian J. Genet., 49 (2), 219-222.

Dhamayanthi, K. P. M. and Reddy, V. R. K. (2001). Inheritance of clustered fruit characters and upright fruit orientation in chilli (Capsicum annuиm L.). J. Spices Aromatic Crops, 10(1), 41-43. 